Insuring perfect and convenient combustion, the apparatus could be extended in its application to the determination of total sulphur in gases and vapors of whatever description. Fuel and illuminating gases are here in mind. It could further doubtless be made to lend itself in many instances advantageously to sulphur determinations in the ultimate analysis of organic compounds.

I.ABORATORY OF THE SEMET-SOLVAY CO.

SYRACUSE, N. Y.

\title{
THE SYSTEM LIME, GYPSUM, WATER, AT $25^{\circ} .^{1}$
}

By F. K. CAMERoN AND J, M, Bell.

Received June 30 , 1906.

THE three-component system-lime, sulphuric acid, water-has been studied in this laboratory by Cameron and Breazeale. ${ }^{2}$ In this work the composition of solutions containing an excess of the acid has been investigated over a wide range of concentration. In all solutions up to 300 grams of $\mathrm{SO}_{3}$ per liter the stable solid phase is gypsum. We have investigated the composition of solutions in which the lime has been in excess of the acid.

Two series of solutions have been prepared, one, various lime solutions to which solid gypsum has been added, and the other, various gypsum solutions to which lime has been added. These bottles were put in the thermostat at $25^{\circ}$ and were rotated constantly for a period of two weeks. At the end of this time known volumes were analyzed for lime and for sulphuric acid. These results are given in the following table:

TABLE I.

$\mathrm{SO}_{3}$ per liter.

0.0

0.230

0.392

0.562

0.714

0.934

$0.96 \mathrm{I}$

I.OI 3

I.090

I. 28

I. 194

I. $25 \mathrm{I}$
CaO per liter.

Grams.

I. 166

I. 302

I. 424

I. 608

I. 742

I. 876

I. $6 \mathrm{I}_{2}$

I. 320

I. I I 2

0.966

0.898

0.875

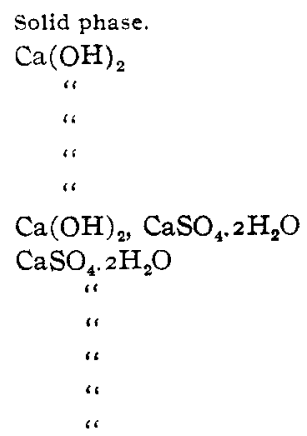

1 Published by permission of the Secretary of Agriculture.

2 J. Physic. Chem. 7, 57 I (I903). 
The results in the above table have been calculated to the amounts of calcium sulphate and of lime in the solution and are given in Table II. They are charted in the accompanying diagram.

\section{TABLE II.}

\begin{tabular}{|c|c|c|}
\hline $\begin{array}{c}\mathrm{CaSO}_{4} \text { per liter. } \\
\text { Grams. }\end{array}$ & $\begin{array}{c}\mathrm{CaO} \text { per liter. } \\
\text { Grams. }\end{array}$ & Solid phase. \\
\hline 0.0 & I. 166 & $\mathrm{Ca}(\mathrm{OH})_{2}$ \\
\hline 0.391 & I. I 4I & " \\
\hline 0.666 & I. I 50 & \\
\hline 0.955 & I. 215 & “ \\
\hline $\mathrm{I} .2 \mathrm{I} 4$ & I. 242 & " \\
\hline I. 588 & $I .222$ & $\mathrm{Ca}(\mathrm{OH})_{2}, \mathrm{CaSO}_{4} \cdot 2 \mathrm{H}_{2} \mathrm{O}$ \\
\hline 1.634 & 0.939 & $\mathrm{CaSO}_{4} \cdot 2 \mathrm{H}_{2} \mathrm{O}$ \\
\hline 1.722 & $0.6 \mathrm{II}$ & " \\
\hline I. 853 & 0.349 & is \\
\hline 1.918 & 0.176 & $" r$ \\
\hline 2.030 & 0.062 & " \\
\hline 2.126 & 0.0 & " \\
\hline
\end{tabular}

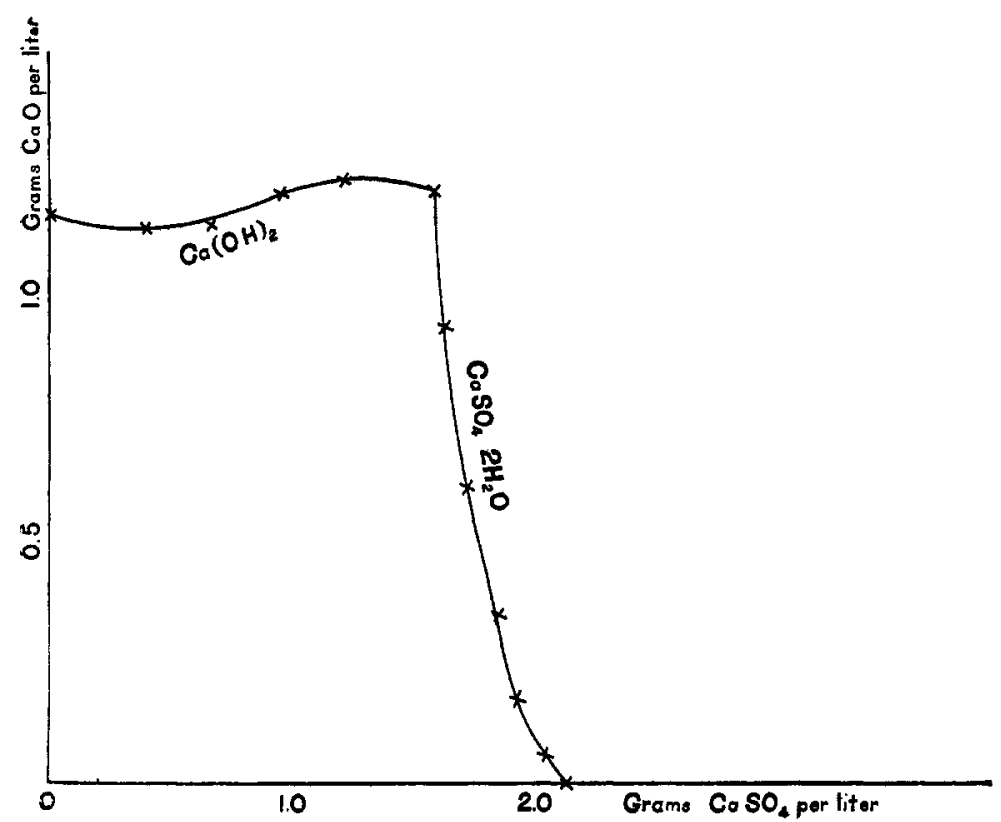

These figures indicate that the solubility of lime in gypsum solutions is constant within a few per cent., the solubility being greater in the more concentrated solutions. In lime solutions, 
however, the solubility of gypsun decreases regularly as the amount of lime in solution increases.

BUREAL OF SOILS,

U. S. DEPARTMENT OF AgRICLLTURE,

WASHINGTON, D. C.

THE PHOSPHATES OF CALCIUM, III; SUPERPHOSPHATE. ${ }^{1}$

By F. K. CaMeroy and J. M. Bell.

Received June 28, 1906.

IN former papers ${ }^{2}$ from this laboratory, the three-component system-lime, phosphoric acid, water-has been investigated at $25^{\circ}$. It was found that there are three solubility curves, one representing solutions in equilibrium with monocalcium phosphate, $\left(\mathrm{CaH}_{4}\left(\mathrm{PO}_{4}\right)_{2} \cdot \mathrm{H}_{2} \mathrm{O}\right)$, one representing solutions in equilibrium with dicalcium phosphate, $\left(\mathrm{CaHPO}_{4} \cdot 2 \mathrm{H}_{2} \mathrm{O}\right)$, and the third representing solutions in equilibrium with a series of solid solutions. The compositions of these solid solutions extend from pure lime to a solution of nearly the same composition as dicalcium phosphate. Another three-component system - lime, sulphuric acid, water-has been studied in this laboratory. ${ }^{3}$ The composition of solutions

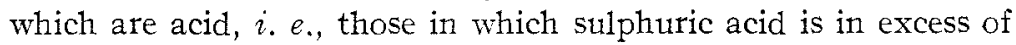
lime, has been published in the former paper, while the composition of solutions which are alkaline has been investigated in the second paper. Only one solid phase was found in this first investigation, viz., gypsum $\left(\mathrm{CaSO}_{4} \cdot 2 \mathrm{H}_{2} \mathrm{O}\right)$. Had that investigation extended to more concentrated solutions of sulphuric acid, another solid phase, anhydrite $\left(\mathrm{CaSO}_{4}\right)$, would undoubtedly have been found. In the case of the alkaline solutions, two solid phases were found, calcium hydroxide and gypsum. In solutions containing less than I.22 grams of free lime per liter the solid phase was found to be calcium hydroxide.

This present investigation deals with the four-component system-lime, phosphoric acid, sulphuric acid, water-the essential constituents of the so-called "superphosphates."

A complete representation of the conditions obtaining in any four-component system can be attained only by the use of a space

1 Published by permission of the Secretary of Agriculture.

2 Cameron and Seidell: This Journal; 27, I503 (Ig05); Cameron and Bell: Ibid., 27, 1512 (1905).

${ }^{3}$ Cameron and Breazeale: J. Physic. Chem. 7,57I (1903); Cameron and Bell: This Journal, 28, 1220 (I906). 